\title{
De-politicizing language: obstacles to political theory's engagement with language policy
}

\author{
Peter Ives
}

Received: 22 October 2013/ Accepted: 19 May 2014

(C) Springer Science+Business Media Dordrecht 2014

\begin{abstract}
This article argues that while there exists considerable overlap and potentially productive dialogue between political theory and language policy scholarship, any such effort will be hampered by the dominant approaches to political theory that assume individualistic and instrumentalist conceptions of language. Augmenting the language ideologies approach to such questions, I argue that within political theory there are resources to address such issues. After summarizing a few key contributions of recent political theory to debates on linguistic justice and language rights, the article turns to the writings of John Locke to analyze the underlying conception of language in these approaches. It concludes by suggesting that the key developments that language scholars have focused on in terms of the rise of global English, questions of native versus non-native ownership of language, changes in the nation-state and the context of global capitalism create the conditions in which such liberal and individualistic are unlikely to have significant purchase for scholars of language and language policy. I conclude by suggesting other theoretical resources that yield more attractive perspectives including Antonio Gramsci, Valentin Vološinov and Mikhail Bakhtin.
\end{abstract}

Keywords Language rights · Linguistic ideology $\cdot$ Philosophy of language $\cdot$ Linguistic justice $\cdot$ Political theory $\cdot$ Liberalism

\section{Introduction}

In recent years, there has been an increasingly rich literature in political theory dealing with language rights and linguistic justice. This work has raised key themes

Political Science Department, University of Winnipeg, 515 Portage Ave., Winnipeg, 
that overlap with concerns of scholars of language policy (for succinct overviews see De Schutter 2007; Patten 2009; see also Kymlicka and Patten 2003; Van Parijs 2011; Schmidt 2005; Peled 2011). Nevertheless, bringing these two approaches together proves difficult, not only due to the usual obstacles of disciplinary boundaries, differences in terminology and the general push towards specialization pervasive throughout academic knowledge production, although these impediments are certainly obtrusive in this case too (see Peled, this volume). As De Schutter explains, political philosophers involved with debates about linguistic justice and normative political theory are "not concerned with the study of actual language policies or with empirical research on linguistic diversity" but instead deal "uniquely with the just political reaction towards languages" (De Schutter 2007: 2). However, as we shall see below, normative political theorists use examples and analyses of actual language policies and empirical situations to bolster their normative positions. Moreover, as I will argue, the lack of engagement with research done by language scholars is more than a matter of the predilections of this group of theorists. Instead, it reflects the dominance of a particular tradition and methodology within political theory to the detriment of other approaches that also engage in systematic and analytic exploration of key ideas of justice, power, freedom and the role of the state. This article will tease out the central effects and assumptions that the underlying commitment to liberal individualism has on much political theory engaged with linguistic justice, language politics and policy.

Language scholarship cannot be accused of ignoring normative questions of how questions of justice are related to language usage. Most explicitly, the concept of linguistic or language ideology addresses, among other themes, the normative assumptions concerning language usage connecting them to empirical research on linguistic usage and diversity. In her summary of the diversity of approaches to ideologies of language, Kathryn Woolard notes that they all "envision and enact ties of language to identity, to aesthetics, to morality, and to epistemology" (Woolard 1998: 3). For normative political theorists, as will be explored below, the links between language and morality are paramount, but these other related relations are also central (aesthetics being perhaps the most neglected). Most pertinent to my contribution here, Bauman and Briggs have used the concept of language ideology to illustrate the construction of modernity that hinged upon inequality organized by "purifying" language as a separate domain from social relations and conflicts (Bauman and Briggs 2003). My argument complements and augments Bauman and Briggs' work, and especially the centrality of the writings of John Locke in articulating the dominant liberal individualist ideology. I extend this analysis by connecting Locke's focus on language as primarily a vehicle of transmitting ideas among individuals to contemporary analyses of linguistic justice, language politics and policy. I add to the language ideology approach in order to emphasize not only the underlying continuities between Locke's seventeenth century liberalism and those that are mobilized today by political theorists, but also to highlight many of the discontinuities and assumptions within this ideology especially those that prevent normative political theory from addressing key historical changes or trends concerning the growing use of English around the globe and the linguistic dimensions of global capitalism. While it is beyond the purview of this current 
article, my larger concern is that the precepts of liberal individualism as framed by Locke and repeated in recent political theory prevents an analysis of some of the most significant developments in language usage occurring today. These developments, which language scholars have raised, include the status of a 'mother tongue' or 'native language' given the enormous increase in non-native users of English across the globe (e.g. Crystal 2003; Ives 2006) and the commodification of languages in global capitalism (Duchêne and Heller 2012). I think that where political theory is seriously remiss is in its inability to fulfill its function of providing a nuanced understanding of the changing terrain of the state and power relationship. I suggest here that until we have a more thorough examination of the Lockean precepts to current theory, bridging the gap between normative political theory and more empirically based language scholarship will be an insoluble puzzle.

From the perspective of language ideology, we can be critical of any given ideological approach's lack of awareness of its own preconceived tenets and we could even explain its inability to engage with developments in empirical language research since as an ideology its positions are already decided. Various approaches to language ideologies allow us to question such underlying conceptions and thus open them up to greater scrutiny through empirical research (see Woolard 1998: 5-9). Much of the work for such an analysis has already been carried out by Bauman and Briggs. My approach is consonant with such language ideology approaches, but instead of viewing current examples of normative political theory as mere redeployment of Lockean language ideology, I will follow the more textual approach of political theory in order to highlight the specific tensions and conflicts concerning specific concepts, most specifically the state, coercion and consent. This analysis is to set the groundwork for a larger project focusing on the nation-state's historical role in 'standardizing' languages (never fully successful), utilizing the notion of the 'mother tongue' (see Gambarota 2011) and current questions of language within global capitalism.

\section{Linguistic justice in a Lockean framework}

I will begin with the work of Philippe Van Parijs on linguistic justice and then turn to other contemporary normative political theorists. My point is to show that while all these theorists grapple with complexities of language and its various political dimensions drawing on empirical examples to support their positions, their conclusions rest on an individualist and transmission defined notion of language. Other considerations concerning questions of identity, symbolic value and most importantly broader power structures that are often substantiated by language and inequality amongst the status of different languages or language varieties are then trumped by language as a (pure or neutral) system of communication amongst individuals. I will then trace these assumptions about what language is back to the writings of John Locke.

Van Parijs begins by maintaining that " $[\mathrm{t}]$ he mechanism through which linguistic competence spreads in a population can be given..." by what he calls, "probabilitydriven learning" which is "partly a matter of expected benefit." He then labels this 
“expected communicative benefit" (Van Parijs 2011; 11-12). ${ }^{1}$ Given this individualist presumption that language is fundamentally about transferring ideas from one individual to others, it is thus unsurprising that he argues, although with little evidence or empirical support, that "At a stunning pace, competence in English is spreading throughout Europe and throughout the world. This massive irreversible phenomenon, I shall argue, must be welcomed. Yet it generates injustices, which the core of [this] book will consist in exploring" (Van Parijs 2011: 3). He further elaborates a central "mechanism" by which individual speakers choose (or should choose) to employ a given language in any context of "speakers" with different "mother tongues." He stipulates, "When having to address a multilingual audience-from a single person to a crowd-you will spontaneously ask yourself whether there is any language that is known to some extent by yourself and everyone else involved" (Van Parijs 2011: 14). He calls this the "max-min criterion," distinguishing it from other options including the egocentric (choosing your most comfortable language), the democratic (the language spoken best by the majority), or a "fair division" whereby you speak all the languages you know that your audience knows. Van Parijs maintains that this max-min mechanism achieves the best (or maximum) possible effective communication while minimizing exclusion of speakers involved. This max-min dynamic combined with probability-driven learning is the guiding theme of Van Parijs' theory of linguistic justice, creating a "positive feedback loop" that, he claims, both explains the massive spread of English as a lingua franca and sets the framework for determining the dimensions of justice that need to be considered.

What is important here is how Van Parijs addresses other aspects of language that do not fit this individualist, transmission approach to language. Initially he addresses "deviations" from these main processes as either didactic or symbolic (Van Parijs 2011: 17-19). He then adds "power relations" as a third source of "deviation" from this max-min logic. But he writes off this third source of deviation from his main guiding principles as "only a minor magnitude" arguing that "power will not prevent the max-min criterion from running the show any more than didactic or symbolic concerns" and that his core mechanisms of probability-driven learning and max-min use determine "language dissemination under contemporary conditions" (Van Parijs 2011: 20-21). As we shall see below, the role of the state especially in defining educational requirements and options is seriously ignored. A reader may wonder how all these claims can be made without support from empirical evidence or thorough considerations of alternate views. And this in a book published by Oxford University Press in the prestigious 'Oxford Political Theory' series. The obvious answer seems to be the dominance of the Lockean presumptions about language examined below.

Not unlike many other scholars (e.g. Brutt-Griffler 2002; Crystal 2003; De Swaan 2001), the current dominance of English is viewed by Van Parijs as resulting from the world's need for a lingua franca enabling communication across the globe. The history of colonialism and other explicit uses of military,

\footnotetext{
${ }^{1}$ Van Parjis defines "probability driven learning" as resulting from the opportunity to both learn and use a given language.
} 
economic and cultural hegemony to ensure the status, prestige and prevalence of English are noted but demoted as negligible next to the communicative powers that English provides (see Ives 2010: 521). The unevenness of the need for a global lingua franca and the details of the policy implications are considered by Van Parijs only through broad dynamics of linguistic justice. Importantly, he devotes a chapter to the need for "parity of esteem" among languages. He admits that linguistic justice may entail redress required by the need for "equal respect [of languages] that is irreducible to the equalization of opportunities" (Van Parijs 2011: 119). Here he accepts that language is more than a (neutral) vehicle of communication and goes beyond a purely Lockean approach to language, however he insists that transmission of ideas is still its defining function.

After seeming to take non-instrumental concerns into account, he concludes that various "symbolic" attempts to ensure equal esteem among languages are "too costly," "pointless," "time-consuming" and "tedious." His final conclusion is that there is only one practical avenue to address equality among languages, which is a territoriality principles allowing coercive language policies within a local context on the proviso that the communities that opt for such policies pay all the costs. Van Parijs summarizes his lengthy discussion this way, "it is perfectly fine to allow and even accelerate the spreading of competence in English, but at the same time we must introduce or reaffirm a territorially differentiated coercive linguistic regime that makes it realistic to expect immigrants to learn weaker local languages, makes it possible to counteract or reverse the latter's slow agony, and makes it legitimate to make them the political languages of the territories concerned" (Van Parijs 2011: 174). In this way, the instrumental use of a language like English to transfer ideas is placed in the realm of consent of individuals, whereas questions of identity, 'symbolism' and esteem are aligned with coercion of individuals by the state. Van Parijs, contrary to Locke as will be discussed, is willing to allow such coercion by the state based on the territorial principle concerning language policy depending on the empirical situation as potentially just. However, this in effect reinforces his default position of linguistic justice as that of the realm of 'consent' based on individuals using language as a vehicle of communication.

Van Parjis continually avoids or constrains any serious consideration of struggles over what version of a language is adopted, how languages are standardized, and all the real world dynamics that scholars as diverse as Braj Kachru, Lisa Mitchell or Benedict Anderson raise (Kachru 2005; Mitchell 2009; Anderson 1991). Moreover, he ignores the fact that the vast majority of those learning English today do so within state policies concerning education rather than as individuals making abstract choices among a host of equally available options. As we shall see, on these issues, Van Parijs' initial assumptions about what language is are perfectly matched with John Locke's theory of language. While he addresses many of the countervailing aspects of language politics that Locke ignores entirely, Van Parijs is able to demote or explain such issues away precisely because he begins with a fundamentally Lockean approach to language. 


\section{Contemporary debates in normative liberal theory}

In the influential collection of essays, Language Rights and Political Theory (2003), edited by Will Kymlicka and Alan Patten, there are several similar, if not as extensive, examples of how normative political theory rests on this Lockean approach to language. Ruth Rubio-Marín provides perhaps the clearest example of how priority is given to language as an instrument of transmission of ideas among individuals. While initially presented as an analytic distinction between noninstrumental and instrumental language rights, Rubio-Marín champions instrumental language rights at the expense of other considerations. She argues "the aim of instrumental language rights is not the protection of one's linguistic or cultural identity but the overcoming of language obstacles so as to enjoy in a minimally significant way a given right or freedom that rests on the possibility of linguistic interactions" (Rubio-Marín 2003: 74-75). While she considers the importance of what she sees as non-linguistic language rights concerning culture and identity, she ultimately falls back on the argument that language is more fundamentally about communication among individuals, and the goal is to "avoid linguistic obstacles that may curtail the enjoyment of rights, freedoms, and opportunities that rest on the possibility of comprehensible linguistic interaction..." (Rubio-Martin 2003: 68).

In the same collection, Thomas Pogge offers a critique of Will Kymlicka's general theory of 'group rights.' ${ }^{2}$ Within this analysis Pogge presents an approach to language rights premised on a similar reduction of language to a tool of transmission, as Locke provides. He focuses on the situation of children in the United States, asking whether Spanish speaking students have any right to education in Spanish. Pogge uses this as an example of more general propositions about whether it should be seen as an unjust inequality to force all children to learn the dominant language. His conclusion erases any specificity of language, "To summarize after two steps: I have proposed a Fundamental Principle of Public Education, holding roughly, that the best education for each child is the education that is best for this child.... the fundamental duty of a just public education system is to promote the best interests of each and every child and to do so equally. This duty must trump any desire to increase or decrease the prominence of this or that language or culture in the US" (Pogge 2003: 118). While Pogge makes various caveats about not being an expert on education and the benefits or disadvantages of learning in one's non-native language (Pogge 2003: 118), language as a topic of politics, considerations of the political value of linguistic diversity, of multilingual citizens, and of how language assimilation has played a role in the dominance of some cultures and social groups over others, drop out of Pogge's argument. It is as if these children do not live in the social world where questions of language, its history and multiplicity, have an impact on individuals, except their ability to communicate with others. Language is merely lumped in with an amorphous concept of culture as some object that cannot trump individually accessed questions of equality. The

\footnotetext{
${ }^{2}$ Will Kymlicka offers a much more complex case of a normative political theorist engaged in language politics and policy questions. While his approach does not fit so neatly into a Lockean approach to language, I have argued elsewhere that his liberal individualism also prevents his theory from being able to grapple with recent developments in language policy and practice, see Ives 2014 forthcoming).
} 
unstated premise of Pogge's entire account is that language is fundamentally about individuals being able to transmit information to others. Children learn language so that they can increase their potential income earnings. Children are harmed if they are denied the tools that enable them as individuals to achieve specific goals gauged in earning potentials. Questions of the harms of assimilation into the dominant language and culture or the more general political terrain being defined through the suppression or subjugation of minority languages are marginalized by the presumption that language is first and foremost a vehicle of transmitting ideas from one individual to others.

Turning to a rather different example from the same collection, Daniel Weinstock offers a nuanced analysis favouring states following a policy of benign neglect as much as possible or reasonable when it comes to language policy. He distinguishes three different "functions" that language serves, the first being an instrument of communication, the second that language provide "access to culture" and the third that they "anchor their identities" (Weinstock 2003: 250). While I do not want to reduce the complexities of his analysis, his basic argument rests on a privileging of the first, "communicative efficacy," when it comes into conflict with the other two. As he writes, "Defenders of language policies that justify the overriding of individual language choices on the basis of an analogy with public goods thus make the assumption that communicative efficacy is systematically trumped in individuals' 'authentic' preference schedules (depending on the case) the desire to keep faith with one's historical roots or the wish to be part of a homogeneous societal culture" (Weinstock 2003: 264). Weinstock argues that if there is indisputable evidence that all the minority individuals involved value access to minority culture and want to be anchored to their minority identities, only then can these functions of language over-ride the communicative function of language. But barring such indisputable evidence (which would seem impossible to actually determine as an indisputable fact without pre-empting democracy as a complicated set of arrangements), Weinstock argues that states should opt for a language policy that privileges the minimal criteria of its ability to "communicate effectively with their citizenry, but no more" (Weinstock 2003: 265). Of course, it is very tricky to determine on what basis individuals make such supposedly "individual language choices" as if they are not embedded within social contexts and as if choices over what language(s) to learn and use are not inherently social depending on who else is using these languages and what the structural implications of those choices are. Unless we are discussing utopian societies with no history of colonialism where power and resources are distributed equally, most individuals making a language choice will be making it at the mercy of others with greater power and resources. While on the face of it, Weinstock does not rule out valuing language for other reasons than mere transmission of communication among individuals, his position relegates the democratic state to a minimalist position that will have a similar effect to that of Locke's approach to language.

The underlying pattern is that to the extent that language is defined as primarily about ideas passing among individuals (i.e. effective communication), questions of struggle over language are decided in favour of the common, dominant language, since it will best facilitate communication if seen as a strictly individual activity of 
communication across society. At best, the political theorists examined above admit that language in addition to being an instrument of individual communication, may be a terrain of struggle, a source of collective identity or recognition, and the like, but by holding the initial function as primary, they all position the state as having either a minimal role or one that fosters the dominant language. Within Kymlicka and Patten's volume, the clearest exceptions to the presumed Lockean picture of language are the essays by Stephen May and Denise Réaume, neither of whom are political theorists by profession and they constitute a minority position in the collection. The other contributions remain ambiguous about these questions leaving the Lockean approach unchallenged.

These are just some examples within recent work in political theory concerning language, but they confirm the dominant pattern as accurately described by Alan Patten's overview of language issues within normative political theory. Patten narrows this field by asking what type of complaints would minority-language speakers be able to level against monolingual language policies since, as he contends not unproblematically, "the case for state monolingualism is widely accepted and fairly compelling" (Patten 2009: 103). He distinguishes between complaints that are "personal," i.e. that are on behalf of particular languages belonging to particular individuals, versus those that that are "impersonal" complaints on behalf of society at large or humanity. Oddly, though perhaps true to the nature of the literature being summarized, Patten shifts seamlessly into the former category, not even explaining why his survey does not address such potential "impersonal" complaints. Thus, without explicitly addressing the nature of language, its social and communal character or questions of mother tongue and competency, Patten has reinforced the fundamental perspective that we shall see explicitly laid out by John Locke.

\section{Historical roots of contemporary assumptions about language}

One puzzling and problematic characteristic of these contemporary political theories of linguistic justice and rights is their lack of historical perspective on the centrality of language to modern political theory. They leave the impression that the history of political theory has nothing to do with contemporary questions of language rights (notable exceptions include Peled 2011: 442; De Schutter 2007: 8, see also Schimdt, Sr., this volume). ${ }^{3}$ Before I show how the underlying premises of the previously considered work adhere to Locke's theorization of language, it is important to note that the ontological individualism of social contract theory does not necessarily lead to the specific conclusion of Locke's transmission theory of language being inadequate for our current global contexts. This is one of the reasons why the

\footnotetext{
${ }^{3}$ While I agree with Yael Peled and Helder De Schutter that there is a problem with the gap between the complex analytical tools based on abstraction and the 'real world,' empirical language studies concerned with implementation of policy and sociolinguistic research (Peled 2011: 441-443; De Schutter 2007: 2-4), here I am more concerned with the gaps within the theoretical side, gaps which obscure the role that theory is supposed to be able to play.
} 
language ideology approach of many linguistic anthropologists, including that of Bauman and Briggs, should be augmented by more specific work in political theory.

To highlight the specific gaps in Locke's approach to language that become an impediment to normative political theory's ability to contribute to current developments in language politics including the advent of 'global English' and the changing role of the states, I will begin with that other seminal seventeenth century theorist, Thomas Hobbes. Ian Hacking notes, Thomas Hobbes' "chief works on political theory, such as Leviathan, all begin with a study of human nature and man's communication. The political animal is necessarily a speaking animal, and to understand politics, thought Hobbes, one needs a good theory of speech" (Hacking 1975: 24). ${ }^{4}$ Philip Pettit goes further, arguing that Hobbes' approach to language is what enables him to overcome Descartes' mind/body dualism, to understand humans' ability to reason and work collectively, but also accounts for humans' propensity to compare themselves with others and become antagonistic towards one another (Pettit 2008).

Without venturing into a full comparison of Hobbes and Locke's theories of language, we can still see, not surprisingly, that they have radically different views concerning the role of the state and language. Sheldon Wolin (2004: 231) notes that one of Hobbes' under-appreciated contributions to political theory is "the recognition that a political order involved more than power, authority, law and institutions: it was a sensitive system of communication dependent upon a system of verbal signs, actions, and gestures bearing generally accepted meaning." For Hobbes, the sovereign had the role and the right to make decisions over meaning and establish a public language (Hobbes 1996 [1651]: 117-120; Pettit 2008: $115-140) .^{5}$ This is a key point to contrast with Locke, who as we shall see rejects the possibility that the state or sovereign could play a role in successful language usage. Note that this is not a political or normative position, that the state should not play such a role, but an ontological one. Locke rejects even specific strategies of language policy such as the use of dictionaries (Locke 1995 [1693]: 422) that could be supported, authorized and funded by the state.

\section{Language and politics in John Locke's liberalism}

Hannah Dawson has convincingly shown the inextricable connection between Locke's theory of language as presented in his An Essay Concerning Human Understanding and his liberal political theory espoused in his Second Treatise of Government, his most influential work, still required reading in the history of 'Western' political philosophy. Dawson traces out many ways in which Locke's theory of language is a crucial part of his 'social contract' that forms the basis of the

\footnotetext{
${ }^{4}$ Hacking states this contention within his broader argument that Hobbes does not have a theory of meaning, but nonetheless he argues that language is central to Hobbes' political theory with the analogous propositions that individuals are constituted prior to the state and mental discourse constituted prior to public discourse, Hacking (1975: 25).

5 I'd like to thank Joanne Boucher for helping me formulate this distinction between Hobbes and Locke's implications for language policy.
} 
relationship between individuals, born in the state of nature, and government, that institution that makes society 'civil' or 'civilized.' 6

Locke begins Book III of the Essay, entitled "Of Words," by stating that language is "the great instrument and common tie of society" given to humans by God, because He designed us as "sociable creatures." Locke also emphasizes that the meaning of words is defined purely by convention and is thus also a question of sociality, or "common use" (Locke 1995 [1693]: 326). In this way, Locke at least minimally acknowledges that it is in language that political activity (at least in the expanded definition of activity relating to the 'polis' or society) plays itself out, accepting that language is the medium of politics, that is political society. Locke's initial emphasis on language as a communal and social institution is quickly subordinated to, or predicated on, his more individualistic vision at the heart of his liberalism. He defines language as a collection of words that "are the sensible signs of his ideas who uses them" (Locke 1995 [1693]: 323). As Dawson illustrates, Locke's novelty and the content of his argument against the tradition of rhetoric and the grammarians of his day, lies in his sceptical version of empiricism. As she summarizes, "Words only make sense insofar as they coincide with the thoughts of the [individual] language user." That is, words "must signify the ideas of someone, and therefore are limited to the ideas of particular speakers." This is what "shakes the prevailing orthodoxy out of its complacency" according to Dawson (Dawson 2007: 188). As Bauman and Briggs argue, in Locke's writings "[1]anguage was powerfully reimagined as a question of individual words spoken by individual speakers" (Bauman and Briggs 2003: 38, see also Harris and Taylor 1989). As illustrated above, this reimagining seems to still have a strangle hold on much of the recent normative political theory concerning language.

While Locke is sceptical about the ability of language to function correctly due to semantic plurality (that different individuals will attach differing ideas to the same words) and the 'abuse of words,' its purpose is to represent ideas in the minds of humans. Much of Locke's concern over language use is that in practice it falls well short of this communicative function. According to him, speakers often either wilfully abuse language or they are careless and sloppy in using it in order to effectively transmit their ideas to others.

As Dawson explains, for Locke the main source of miscommunication is that "... while meaning is logically prior to language, in communication language is experientially prior to meaning" (Dawson 2007: 241). Locke's central argument is that this problem needs to be overcome through understanding that language is a vehicle for transmitting ideas and thoughts from one individual's mind into others. Logic needs to correct experience because language is not working correctly. Indeed, Locke contends that such departures from this logic account for a large degree of the 'abuse' and his anxiety concerning language. Locke provides a list of five normative rules that people should follow in order to best avoid the 'Abuse of Words' including not to use words without having clear

\footnotetext{
${ }^{6}$ Where Bauman and Briggs emphasize that Locke purifies language as an autonomous domain separate from politics and nature, and at one level, emphasize the commonalities between Locke and Herder's 'modern' view of language, here I am more convinced by Dawson's reading whereby such a purification of language from politics, is a more narrow definition of the political.
} 
distinct ideas that they stand for, to use common meanings and not deviate or create new terms or embellish meanings (a point related to linguistic creativity often related to 'native language' use, that I will address later), to repeatedly make those meanings known and to be consistent with what a given word means (Locke 1995 [1693]: 414-424).

An important tenet of Locke's approach that reverberates in contemporary debates concerning 'global English,' is that language is necessarily based on the consent of the speaker and cannot by definition be the result of coercion, state or otherwise. Locke writes, "Words being voluntary signs, they cannot be voluntary signs imposed by him on things he knows not ... when he represents to himself other men's ideas by some of his own, if he consent to give them the same names that other men do, it is still to his own ideas..." (Locke 1995 [1693]: 324). From this argument, Locke continues to emphasize the role of consent, "... no one hath the power to make others have the same ideas in their minds that he has, when they use the same words that he does. And therefore the great Augustus himself, in the possession of that power which ruled the world, acknowledged he could not make a new Latin word..." (Locke 1995 [1693]: 326). This notion that language usage cannot be legislated has echoes in various arguments about global English from Abram de Swaan to David Crystal (de Swaan 2001; Crystal 2003). But this is an untenable way to understand the significant role the state, as that body holding the monopoly on the legitimate use of coercion, has had on the standardization of languages and the propagation of national languages (e.g. Burke 2004). Linguistic anthropologists have shown us in great detail, the various ways in which, as Susan Philips summarizes, language and language ideologies play a significant role in "imagining of nations in institutions centrally involved in the production of state hegemony" (Philips 1998: 223; see Blommaert and Verschueren 1998; Spitulnik 1998; and Mertz 1998). ${ }^{7}$ A key question now is the extent to which many states are key agents in propagating the learning and use not of national languages, but of English.

Despite Locke's radical, liberal, individualism in terms of language policy, his proposals for correcting the failings of language seem to mirror the general approach of many contemporary normative liberal theories. They use detailed reason to set out an ideal principle of how society should be organized, delineate the limits within which people should behave, and compel reasonable people to agree with them. In other words, much normative political theory concerning itself with language rights or linguistic justice implicitly accepts Locke's view that the role of theory is to demarcate the deviation of language usage from its core function which is transmitting ideas among individuals, as I highlighted above with many examples, Van Parijs most explicitly. Questions of reasoning, identity and power may be addressed or acknowledged, but they need to be rendered as secondary and unfortunate aspects that should be subordinated to language as a tool or vehicle of communication narrowly defined.

\footnotetext{
7 I would be remiss if I cited Philips without questioning her lengthy discussion of Antonio Gramsci in which, amongst other problematic interpretations, she contends "Nor was there a special place for language or language ideologies in the core dimension of his concept of hegemony" (Philips 1998: 215). I have shown in great detail how misguided this position is (Ives 2004).
} 
While less explicit in the examples I discussed, Locke's theory assumes that we are fundamentally monolingual speakers who use a single language, thus, implicitly holding out the 'native speaker' as the model speaker, with the case of non-native speakers being no different from a native-speaker in correctly attaching words to ideas. For Locke the issue of 'competency' that other theorists attribute to the 'native speaker,' is related to questions of the abuse of language or its sloppy and unreasonable usage. As non-native users of English come to out-number native speakers creating important questions of how norms are provided (Kachru 2005; Seidlhofer and Jenkins 2003) and as the very concept of the native-speaker is questioned (Gambarota 2011), Locke's assumptions create severe obstacles to the relevancy of his approach.

Amartya Sen makes a relevant distinction between two different approaches to justice, that here can apply to linguistic justice and language rights. Sen distinguishes between the approach that he labels "transcendental institutionalism" as deployed by Locke, Rousseau, Kant and Rawls from "realization-focused" comparative approaches to justice. The former aims to identify institutional arrangements required for "perfect justice" and "concentrates primarily on getting the institutions right, and it is not directly focused on the actual societies that would ultimately emerge," on the comparative questions of which alternatives are "less unjust" than others (Sen 2009: 5-8ff). ${ }^{8}$ This also applies to Locke's understanding of the "perfection" required for communication to actually take place successfully. This idealization of language as communication and casting ambiguity as "abuse," the trickery of rhetoricians and ultimately anathema to the very purpose and essence of language leaves little room for actual political contestation over the meanings of individual words or the nuance of struggle over appropriateness of various choices in style, grammar, accent, tone, vocabulary and the like that make up the rich substance of much current research on 'global English' for example, or other questions of language politics. For Locke, language is merely a tool available to individuals that however necessary to politics does not play a significant role within politics. ${ }^{9}$ Locke derides (in a rather sexist manner) those who disagree with him about the role of language as predominantly a vehicle for communication. Such people, supporters of rhetoric, argues Locke, are impossible to debate seriously, "Eloquence, like the fair sex, has too prevailing beauties in it to suffer itself ever to be spoken against" (Locke 1995 [1693]: 411-412).

To sum up, while Locke is well aware that sharing a specific, public language is related to the ability to form a social compact, enter into political society and create a legitimate government, he finds this a very fragile process because the ideal is for

\footnotetext{
${ }^{8}$ I am less convinced that Rousseau fits so neatly into Sen's distinction here. But this is beyond the scope of this essay and concerns how literal one reads Rousseau's Social Contract.

${ }^{9}$ Even in the few places where Locke discusses the differences between different languages, his point is to emphasize that language originates not in the "steady workmanship of nature" but as "collections [of words] made and abstracted by the mind, in order to naming, and for the convenience of communication" (Locke 1995 [1693]: 351, see also 343). Such problems with translation are not for Locke indications of the importance of social culture to the identity and political consciousness of individuals, but rather proof that words are quite distant from the "things regularly and constantly made by nature, and had a real existence in things" (Locke 1995 [1693]: 351) and thus such variations, Locke notes, are much greater the "more abstract and compounded the ideas."
} 
each speaker to consistently connect words to ideas and for the hearer to decode each word in a similar fashion (Dawson 2007: 291). It is still the function of language primarily and ideally to be a vehicle of the transmission of pre-constituted ideas from one mind to others, which is made problematic and muddled the more the practical recourse to 'common use' is what determines the meaning of words.

There are many ways in which Locke's philosophy of language is antiquated, not the least of which is his focus on language as a collection of words that are labels for ideas that as Roy Harris notes, was out-dated well before Ludwig Wittgenstein and Ferdinand de Saussure mobilized versions of it as a straw dog from which to launch their very influential alternative approaches (Harris 1990: 11-13). Nevertheless, the implications of Locke's focus on language as primarily an instrument of mere communication is alive, well and flourishing in debates concerning 'global English' (inter alia De Swaan 2001; Van Parijs 2011; Seidlhofer and Jenkins 2003; see Ives 2006) as well as in normative political theory concerned with language, as discussed above.

It may seem intuitive and sensible to see language as primarily about communicating among individuals, perhaps with 'symbolic' issues of 'identity' or 'culture' as important, but secondary features. But this view was harshly rejected by Jean-Jacques Rousseau and Johann Gottfried Herder, in different ways. For Rousseau, this type of communication is not a distinctive feature of human language, but is common among animals. True human language, for Rousseau, is born not of "need" but of "passion," of "expression" that goes well beyond mere communication in Locke's sense (Rousseau 1966 [1781]: 8-12). Herder argued that human language, again distinct from the mere transmission of ideas, necessarily involves "self-reflection" which he insisted is central to "reason" (Herder 1966 [1772]: 109-110; see Taylor 1995). I raise these positions here not so much to endorse them against those of Locke, because I think they are equally unable to grapple with current developments of 'global English' and the commodification of language. However, I do want to highlight the wide range of conceptions of language within a fairly narrowly defined tradition of 'Western' political theory. Rousseau and Herder's critiques of Locke's view of language throw into relief how reducing language to a vehicle of communication depoliticizes, or naturalizes, it. In many ways, this debate between Locke and Herder or Rousseau (not that Herder and Rousseau agreed with one another, but both clearly rejected Locke's reduction of language to mere communication) continues today.

As intimated earlier, my point is larger than just asking contemporary political theorists to account for reliance on a Lockean conception of language in the face of very different accounts within modern "Western" political theory, including Hobbes, Rousseau and Herder. Developments in social and political theory in the twentieth century that among other impacts influenced the theorists of deliberative democracy (see Schmidt, Sr. this volume) would seem to provide the most obvious set of resources for conceptions of language that could help contemporary political theory bridge its gap with current language policy scholarship. There are several obvious candidates. Pierre Bourdieu and his concept of 'linguistic capital' are often referenced by language scholars (Bourdieu [1982] 1991). Along with the more influential literary criticism of Mikhail Bakhtin, Valentin Vološinov explicitly 
theorizes language as a terrain of struggle where meaning, accent and identity are not just transmitted but are negotiated or embattled outcomes of complex linguistic interaction (Vološinov [1929] 1986). Antonio Gramsci, whose concept of hegemony often used with no reference to its roots in linguistics is prevalent across many fields including language policy and sociolinguistics, argues that the normative grammar of any language is the result of a political act or project (Gramsci [1935] Gramcsi 1985; see also Ives 2004). This is clearly not the place to embark on an exploration of these and other thinkers but it is quite clear that political theorists have available to them many more systematic and rigorously articulated conceptions of language than that provided by John Locke. And it is from these sources that political theory is more likely going to be able to bridge the gap between its own methods and the important research being conducted within language policy and other subfields of the language sciences.

\section{Conclusion}

Braj Kachru makes the bold claim that no doubt has a fundamental aspect of truth to it, "For the first time in linguistic history a language [English] has established contact with practically every language family in all the continents, both formally and functionally" (Kachru 2005: 99). This is the current context for all language politics and rather than trying to escape its implications, the role of political theory should be to provide adequate tools for theorizing the complexity of the resulting situations. Summarizing both the positive and the more adverse implications of the impact of English on language use around the globe, Kachru notes that "Whatever the future reveals, it is obvious that the spread of English, the degree of Englishization of the languages of the world, and the development of varieties of English and English-based codes raise a wide variety of theoretical, methodological, ideational, and applied issues" (Kachru 2005: 117). Indeed, the complexities raised by the massive numbers of non-native users of English are truly enormous especially in relation to political issues from language policy and planning to rights and justice. That there has been so little cross fertilization of ideas between normative political theory and language studies is obviously a detriment to our abilities to understand and respond to the challenges history has presented us. My hope is that by acknowledging the simultaneity of language as a medium and object of politics, and theorizing core concepts like 'native speaker' with open and critical eyes, greater productive communication can occur among diverse sets of scholars.

\section{References}

Anderson, B. (1991). Imagined communities. Revised Edition. London: Verso.

Bauman, R., \& Briggs, C. (2003). Voices of modernity: Language ideologies and the politics of inequality. Cambridge: Cambridge University Press.

Blommaert, J., \& Verschueren, J. (1998). The role of language in European nationalist ideologies. In B. Ambi Schieffelin, K. Woolard, \& P. Kroskrity (Eds.), Language ideologies: Practice and theory (pp. 189-210). Oxford: Oxford University Press. 
Bourdieu, P. (1991 [1982]). Language and symbolic power. Cambridge, Ma.: Harvard University Press. Brutt-Griffler, J. (2002). World English: A study of its development. Clevedon: Multilingual Matters.

Burke, P. (2004). Languages and communities in early modern Europe. Cambridge: Cambridge University Press.

Crystal, D. (2003). English as a global language (2nd ed.). Cambridge: Cambridge University Press.

Dawson, H. (2007). Locke, language and early-modern philosophy. Cambridge: Cambridge University Press.

De Schutter, H. (2007). Language policy and political philosophy: On the emerging linguistic justice debate. Language Problems \& Language Planning, 31(1), 1-23.

De Swaan, A. (2001). Words of the world. Cambridge: Polity.

Dewey, M., \& Jenkins, J. (2010). English as a Lingua franca in the global context: Interconnectedness, variation and change. In M. Saxena \& T. Omoniyi (Eds.), Contending with globalization in world Englishes (pp. 72-92). Bristol: Multilingual Matters.

Duchêne, A., \& Heller, M. (2012). Language in late capitalism: Pride and profit. London: Routledge.

Gambarota, P. (2011). Irresistible signs: The genius of language and Italian national identity. Toronto: Toronto University Press.

Gramcsi, A. (1985). Selections from cultural writings. Cambridge, Ma: Harvard University Press.

Hacking, I. (1975). Why does language matter to philosophy. Cambridge: Cambridge University Press.

Harris, R. (1990). Language, Saussure and Wittgenstein: How to play games with words. London: Routledge.

Harris, R., \& Taylor, T. (1989). Landmarks in linguistic thought (Vol. 1). London: Routledge.

Herder, J. G. (1966[1772]). Essay on the origin of language. In J. H. Moran (Ed.) and A. Gode (Trans.) On the origin of language (pp. 85-166). Chicago: University of Chicago Press.

Hobbes, T. (1996 [1651]). In R. Tuck (Ed.), The leviathan. Cambridge: Cambridge University Press.

Ives, P. (2004). Gramsci's politics of language: Engaging the Bakhtin circle and the Franfurt school. Toronto: University of Toronto Press.

Ives, P. (2006). 'Global English': Linguistic imperialism or practical lingua franca? Studies in Language and Capitalism, 1, 121-141.

Ives, P. (2010). Cosmopolitanism and global English: Language politics in globalisation debates. Political Studies, 58, 516-535.

Ives, P. (2014 forthcoming). Global English and the limits of liberalism: Confronting global capitalism and multiculturalism. In T. Ricento (Ed.) Language policy and political economy: English in a global context. Oxford: Oxford University Press.

Kachru, B. (2005). Asian Englishes: Beyond the canon. Hong Kong: Hong Kong University Press.

Kymlicka, W., \& Patten, A. (Eds.). (2003). Language rights and political theory. Oxford: Oxford University Press.

Locke, J. (1995 [1693]). An essay concerning human understanding. Amherst, N.Y.: Prometheus Books.

Mertz, E. (1998). Linguistic ideology and Praxis in U.S. law school Classrooms. In B. Schieffelin, K. Woolard, \& P. Kroskrity (Eds.), Language ideologies: practice and theory (pp. 149-162). Oxford: Oxford University Press.

Mitchell, L. (2009). Language, emotion, and politics in South India: The making of a mother tongue. Bloomington: Indiana University Press.

Patten, A. (2009). Survey article: The justification of minority language rights. The Journal of Political Philosophy, 17(1), 102-128.

Peled, Y. (2011). Language, rights, and the language and language rights: The need for a new conceptual framework in the political theory of language policy. Journal of Language and Politics, 10(3), 436-456.

Pettit, P. (2008). Made with words: Hobbes on language, mind, and politics. Princeton: Princeton University Press.

Philips, S. (1998). Language ideologies in institutions of power. In B. Schieffelin, K. Woolard, \& P. Kroskrity (Eds.), Language ideologies: Practice and theory (pp. 211-225). Oxford: Oxford University Press.

Pogge, T. (2003). Accommodation rights for hispanics in the United States. In W. Kymlicka \& A. Patten (Eds.), Language rights and political theory (pp. 105-122). Oxford: Oxford University Press.

Rousseau, J.-J. (1966 [1781]). Essay on the origin of languages. In J. H. Moran (Ed.) and A. Gode (Trans.) On the origin of language (pp. 5-58). Chicago: University of Chicago Press.

Rubio-Marin, R. (2003). Language rights: Exploring the competing rationales. In W. Kymlicka \& A. Patten (Eds.), Language rights and political theory (pp. 52-80). Oxford: Oxford University Press. 
Schmidt, R, Sr. (2000). Language policy and identity politics in the United States. Philadelphia: Temple University Press.

Schmidt, R, Sr. (2005). Political theory and language policy. In T. Ricento (Ed.), An introduction to language policy (pp. 95-110). Oxford: Blackwell.

Seidlhofer, B., \& Jenkins, J. (2003). English as a lingua franca and the politics of property. In C. Mair (Ed.), The politics of English as a world language (pp. 139-154). Amsterdam: Rodopi.

Sen, A. (2009). The idea of justice. Cambridge, Mass.: Harvard University Press.

Spitulnik, D. (1998). Mediating unity and diversity. In B. Schieffelin, K. Woolard, \& P. Kroskrity (Eds.), Language ideologies: Practice and theory (pp. 163-188). Oxford: Oxford University Press.

Taylor, C. (1995). Philosophical arguments. Cambridge, Mass.: Harvard University Press.

Van Parijs, P. (2011). Linguistic justice for Europe and the world. Oxford: Oxford University Press.

Vološinov, V. ([1929] 1986). Marxism and the philosophy of language (trans: Matejka, L., \& I. R. Titunik). Cambridge: Harvard University Press.

Weinstock, D. (2003). The antinomy of language policy. In W. Kymlicka \& A. Patten (Eds.), Language rights and political theory (pp. 250-270). Oxford: Oxford University Press.

Wolin, S. (2004). Politics and vision, expanded edition. Princeton: Princeton University Press.

Woolard, K. (1998). Introduction: Language ideology as a field of inquiry. In B. Schieffelin, K. Woolard, \& P. Kroskrity (Eds.), Language ideologies: Practice and theory (pp. 3-47). Oxford: Oxford University Press.

Peter Ives is Professor of Political Science at the University of Winnipeg, Canada. He is author of Gramsci's Politics of Language: Engaging the Bakhtin Circle and the Frankfurt School (University of Toronto Press, 2004); Language and Hegemony in Gramsci (Pluto Press, 2004) and co-editor with Rocco Lacorte of Gramsci, Language and Translation (Lexington, 2010). His articles on the political implications of the advent of 'global English' have been published in Political Studies, Educational Philosophy and Theory, and Studies in Language and Capitalism as well as various edited collections. His writings have been translated into Spanish, German, Italian, Portuguese and Turkish. He is a member of the editorial collective of ARP Books, an independent progressive publishing house. 